\title{
Persistence of Leishmania antigen in C57BI/6j inbred mice infected with Leishmania (Leishmania) amazonensis
}

\author{
C. Vasconcellos, M.R. Kauffman, M. N. Sotto
}

Department of Dermatology, Hospital do Servidor Público Estadual de São Paulo; Faculdade de Medicina da Universidade de São Paulo, São Paulo, SP.

SUMMARY - PURPose. To develop an animal model for studying mucocutaneous leishmaniasis.

Methods. The hind footpad of C57BI/6j inbred mice was experimentally infected with $10^{7} \mathrm{Leish}$ mania (Leishmania) amazonensis promastigote and the skin was studied through light and electron transmission microscopy and i mmunohistochemistry (PAP) techniques.

RESULTS. There were morphological evidences of cellular immune mechanisms and hypersensitivity reaction after eight weeks of infection and metas-

\section{INTRODUCTION}

Increasing in tourism and labors migration disseminated leishmaniasis throughout the world $\mathrm{d}^{1}$. In the $\mathrm{New}$ World there is a particular expression of the disease called American Tegumentary Leishmaniasis, comprising three clinical features: Localized Leishmaniasis (LCL), Diffuse Cutaneous Leishmaniasis (DCL) and Mucocutaneous Leishmaniasis $(\mathrm{MCL})^{2}$.

Some authors ${ }^{3}$ suggested that $\mathrm{DCL}$ and $\mathrm{MCL}$ could be both originating from L ei shmania (Leishmania) amazonensis $s^{4}$, but the mechanisms by which Leishmania leads to MCL remains obscure, owing mainly to the lack of an appropriate animal model $^{5-6}$.

The great majority of papers concerning to animals' models with different susceptibilities to L. (L.) amazonensis do so from an immunological point of view. Morphologic studies about the inflammatory response of the inoculation site are scarce and brief in follow up periods of infection. The aim of this study is to propose this model to study the human disease, according to the histopathol ogic features of the inoculation site and the clinical aspects, in the course of one-year infection.

\section{MATERIAL AND METHOD}

Animals. Female 40-day-old inbred mice C57BI/ 6j strain from the U niversity of São Paulo Medical School General Col ony was used. The animal s were tasis and well shaped parasites at ultrastructural level by fifty-one weeks post infection. Relapse of infection with mucosa lesions occurred around the $50^{\text {th }}$ week after inoculation.

ConCLUSION. The use of this animal model in long term follow up could be an useful experimental model for human mucocutaneous leishmaniasis.

KEY WORDS: Experimental mucocutaneous leishmaniasis. I nbred mice. Transmission electron microscopy. I mmunohistochemistry.

maintained in plastic cages and received proper food and water ad libitum.

Parasites. Leishmania (Leishmania) amazonensis (WHOM/BR/00L TB 0016) - G. Grimaldi, Fiocruz - RJ. The strain was sustained in the laboratory through sequential passages in BALB/C mice, culture in NNN / BHI medium and reinoculation at hind footpad in mice?

Infection. Experimental groups, each with three animals wereinoculated under ether anesthesia with $50 \mu \mathrm{l}$ of saline solution containing $10^{7}$ Leishmania (Leishmania) amazonensis promastigoteforms in the stationary phase of growth in the right hind footpad of mice. There was one control animal in each experimental group, inoculated under the same conditions with $50 \mu \mathrm{l}$ of sterile saline solution. Three inoculated animals and one control were killed 2, 6, 8, 10, 20 and 51 weeks post inoculation (WPI).

Techniques. F ragments from right hind footpad skin were fixed in buffered $10 \%$ formaldehyde solution, $\mathrm{pH} 7.2$ and processed by usual histology technique and stained with Hematoxilyn and E osin. F ragments from the same tissue were processed for immunohistochemistry (PAP) demonstration of Leishmania antigen in tissues ${ }^{18}$ and for Transmission Electron Microscopy 9 .

The experiment was repeated twice.

\section{RESULTS}

Clinical features. C57BI/6j mice put on weight along the experiment. The animals displayed a 


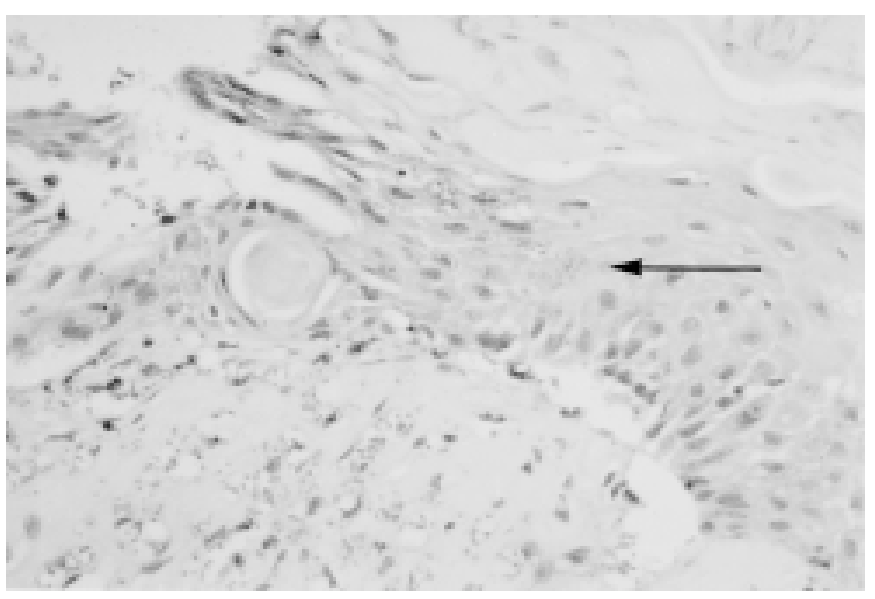

Fig. 1- Hind footpad - elimination of cellular debris and parasites $(\rightarrow)$ through epidermis. Experimental cutaneous leishmaniasis, C57BI/ 6j inbred mice, inoculation of $10^{7} \mathbf{L}$. (L.) amazonensis promastigote forms at right hind footpad ( $20^{\text {th }}$ week post infection, PAP, OM 200x).

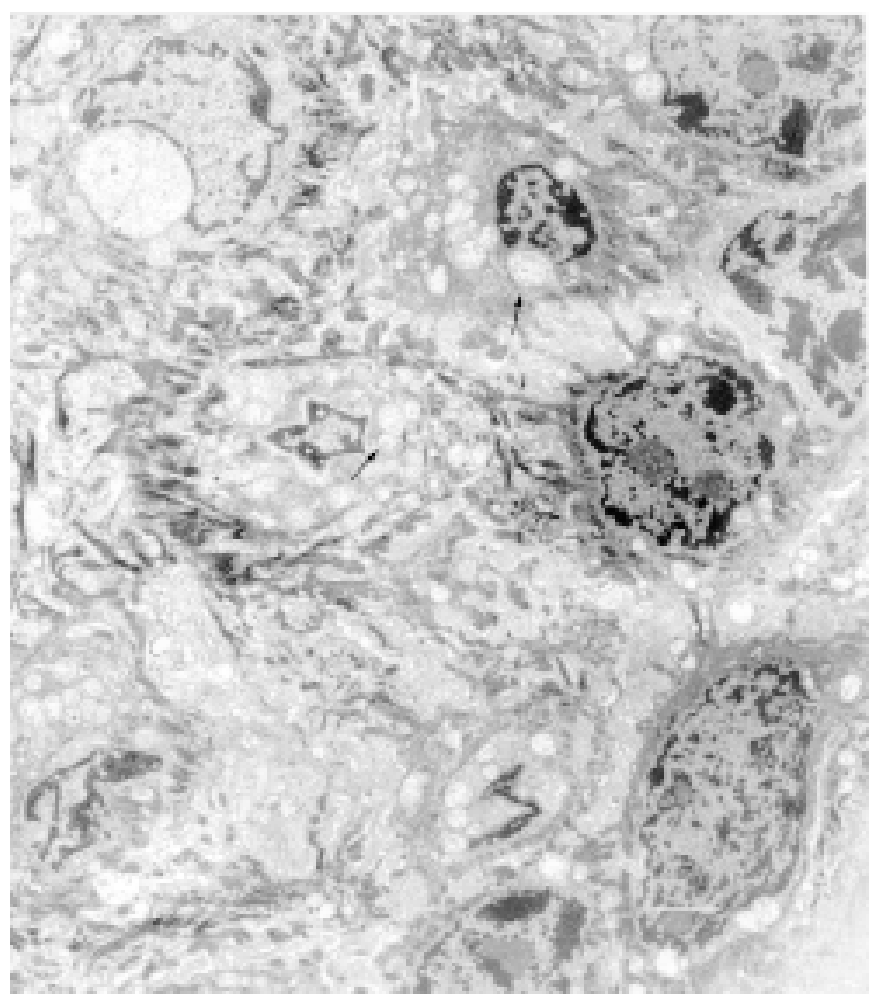

Fig. 2 - Hind footpad - epidermal keratinocytes mitochondria crystolysis $(\rightarrow)$. E sperimental cutaneous leishmaniasis, C57BI/ 6j inbred mi ce, inoculation of $10^{7} \mathbf{L}$. (L.) amazonensis promastigote forms at right hind footpad ( $1^{\text {st }}$ week post infection, Transmission Electron Microscopy, $\operatorname{Bar}=1 \mu \mathrm{m})$.

torpid disease with an apparent healing of hind footpads' cutaneous lesions around $20^{\text {th }}$ WPI. By $50^{\text {th }}$ WPI there was relapse of the lesions at the inoculated footpad and appearance of lesions at the tail and in the nose of all animals.

Histopathology. The C57BI/6j hind footpad dis- closed a rather organized tissue response with granul oma formation after the 8th WPI and fibrosis in the dermis, together with hyperplasia of epidermis, after the 38th WPI. Eosinophils were commonly seen. The nerve endings of the dermis were surrounded by dense macrophage infiltrate very close to the perineurial sheet.

Late in the course of the infection (51st WPI) there were grouped lymphocytes surrounding the vessels of the dermis that showed fibrinoid degeneration. Necrosis was extensive and confluent, coming soon after 2nd WPI and foll owed by granuIoma formation and collagen deposition in the dermis. By the time the dermis of C57BI/6j mice disclosed granuloma formation and collagen deposition, its epidermis displayed exocytosis of mononuclear cells, acanthosis and transepidermal elimination of parasites (evident by the $20^{\text {th }} \mathrm{WPI}$ ). The microscopic aspects of control animals were quite normal.

Immunohistochemistry (PAP). This technique displayed well-shaped amastigotes forms of Leishmania stained in golden brown in the inoculated hind footpad skin. There was no evidence of amorphous antigenic material insidethe cytoplasm of macrophages, as seen in human lesions ${ }^{8}$. By the $20^{\text {th }}$ WPI there was elimination of cellular debris and parasites through the epidermis (Fig. 1).

Transmission electron microscopy. The inoculation site disclosed epidermal keratinocytes mitochondria crystolysis (Fig. 2) throughout the experiment. Some eosinophils showed phagocytised parasites (Fig. 3). There were preserved parasites within macrophages (Fig. 4) and in the extracellular space among collagen fibers of the dermis by 51st WPI.

\section{DISCUSSION}

The epidermis of C57BI/6j mice was clearly involved in the inflammatory process since the beginning of the infection and showed areas of ulceration and hyperplasia. In spite of the presence of parasites in the right hind footpad until the $51^{\text {st }}$ WPI, this animal seems to be able in circumscribing the infection ${ }^{10,11}$. N ecrosis was intense with el imination of parasites through the epi dermis and the granuloma surrounded necrosis foci, which were partially replaced by collagen.

C57BI/6j mice showed a well-developed tissue response (granuloma formation) by the 8th week post infection, in spite of macrophage parasitism. This was coincident with the appearing of morphological evidences of cellular immune mechanisms (granuloma) and of hypersensitivity reaction (fibri- 


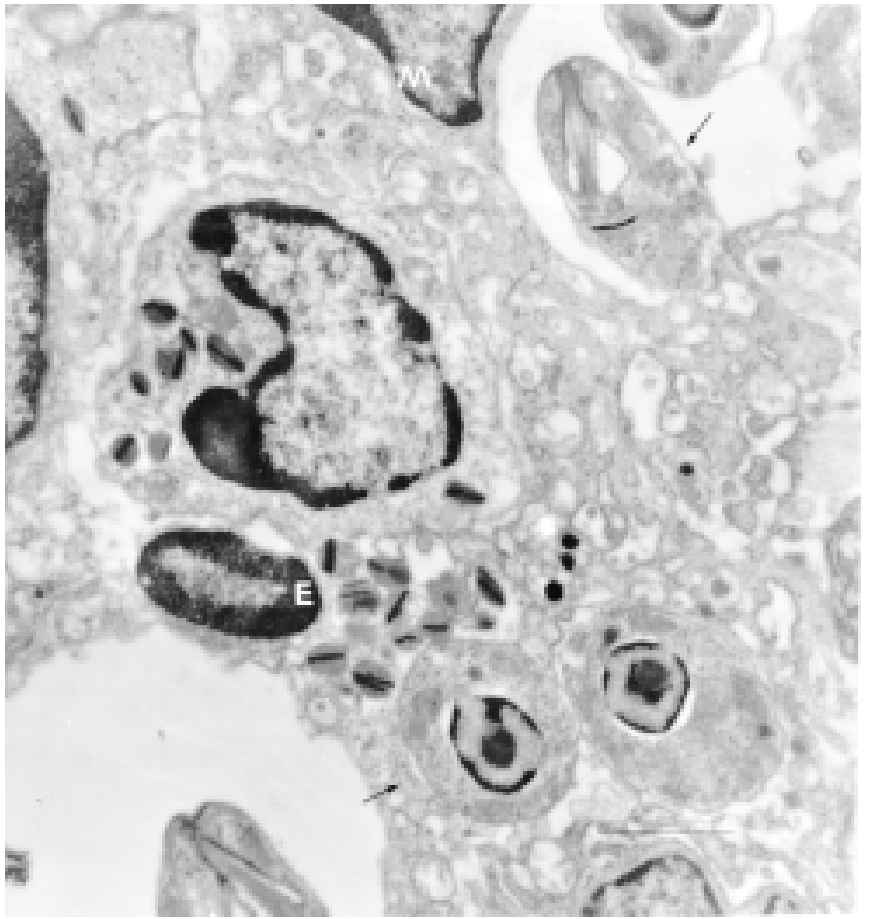

Fig. 3 - Hind footpad - Leishmania amastigoteforms $(\rightarrow)$ inside eosinophil (E). Experimental cutaneous leismaniasis, C57BL/ 6j inbred mice, inoculation of $10^{7} \mathbf{L}$. (L.) amazonensi s promastigote forms at right hind footpad $\left(6^{\text {th }}\right.$ week post infection, Transmission Electron Microscopy, $\operatorname{Bar}=1 \mu \mathrm{m}$ )

noid degeneration of vessel's walls and epidermal aggression by the inflammatory infiltrate). This histologic aspect is similar to that of human Mucocutaneous Leishmaniasis ${ }^{12,13}$. Besides, by the final period of the experiment, cutaneous lesions reappeared mucous lesions appeared and well-preserved parasites could be seen at the ultrastructural level. Thus, such an animal model presented here may be used for experimental studies of human mucocutaneous leishmaniasis.

\section{Acknowledgments}

We are grateful to Ms. Cleusa F. H. Takakura, Carla Pagliari and Debora Aziz Rocha (Department of Pathology FMUSP) who kindly gave us procedure assistance.

\section{RESUMO}

\section{Persistência do antígeno da Leishmania no camundongo isogênico C57BI/6j infectado com a Leishmania (Leishmania) amazonensis.}

Овл ETIVo. Desenvolver um modelo experimental para o estudo da leishmani ose cutâneo-mucosa.

MÉTodos. O coxim plantar traseiro de camundongos isogênicos C57BI/ 6j foi inoculado com $10^{7}$

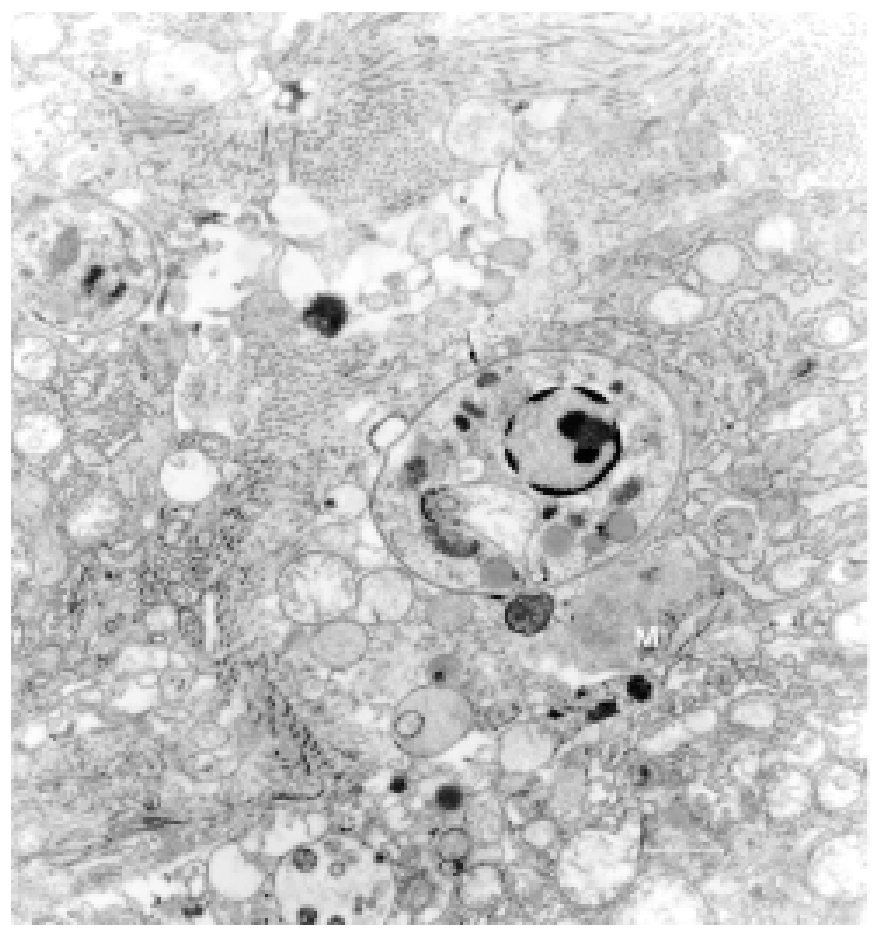

Fig. 4 - Hind footpad - Upriht amastigote forms $(\rightarrow)$ inside macrophge (M). Experimental cutaneous leishmaniasis, C57BI/6j inbred mice, inoculation of 107 L.(L .) a mazonensis promastigote forms at right hind footpad (51st week post infection, Transmi ssi on E lectr on Microscopy, Bar $=1 \mu \mathrm{m})$.

formas promasti gotas da Lei shmania (Leishmania) amazonensis e a pele foi estudada através da microscopia óptica e el etrôni ca ede técnica imunohistoquímica (PAP).

Resultados. Ocorreram evidências morfológicas de mecanismos i munes mediados por células, concomitantemente ao de reação de hi persensibilidade, após a oitava semana de infecção e a presença de parasi tas com ultraestrutura preser vada na quinquagésima primeira semana após a infecção. Houve reci diva da infecção com surgi mento delesões mucosas por vol ta da $50^{\text {a }}$ semana pós inoculação.

ConClusão. Estemodel o animal, com um período de tempo de seguimento prolongado, poderia ser empregado como modelo para o estudo experimental da lei shmani ose cutâneo-mucosa. [ Rev Ass Med Brasil 1999; 45(3): 225-8.]

UNITERMOS: Leishmaniose cutânea experimental. Camundongos isogênicos. Microscopia el etrônica de transmissão. I munohistoquímica.

\section{BIBLIOGRAPHIC REFERENCES}

1. Schuppli R. Leishmaniasis review. Dermatologica 1982; 165: 1-6. 
2. Coutinho E, Coelho M. Leishmaniose tegumentar experimental. III. Patologia comparada da infecção por amostras de Leishmania braziliensis, Leishmania mexicana e Leishmania tropica em animais de laboratório. Rev I nst M ed Trop São Paulo, 1972; 14: 12-29.

3. Barral A, Petersen EA, Sacks DL, Neva FA. Late metastatic leishmaniasis in the mouse. A model for mucocutaneous disease. Am J Trop Med Hyg, 1983; 32: 277-285.

4. Lainson R, Shaw JJ. Evolution, classification and geographical distribution. In Lainson R, Shaw J J eds. The Leishmaniasis in Biology and Medicine, $1^{\text {st }}$ ed. London, W Peters and Killick-Kendrick Academic Press, 1987; 1. 1-120.

5. Childs GE, Lightner LK, McKinney L, Groves MG, Price EE, Hendricks L. Inbred mice as model host for cutaneous leishmaniasis. I. Resistance and susceptibility to infection with Leishmania brasiliensis, L. mexicana and L. æthiopica. Ann Trop Med Parasitol, 198; 478: 25-34.

6. Conceição-Silva F, Dórea RCC, Pirmez C, Schubach A, Coutinho SG. Quantitative studies of Leishmania braziliensis braziliensis reactive $T$ cells in peripheral blood and in the lesions of patients with American Mucocutaneous Leishmaniasis. Clin Exp I mmunol, 1990; 79: 221226.

7. Giorgio S. Estudo da imunidade celular e humoral na imunopatologia e resistência à infecção por L. amazonensis.
Dissertação (Mestrado) - Instituto de Ciências Biomédicas, Universidade de São Paulo, 1989.

8. Sotto MN, Yamashiro-Kanashiro EH, Matta VLR; Brito T. Cutaneous leishmaniasis of the New World: diagnostic immunopathology and antigen pathways in skin and mucosa. Acta Trop. (Basel), 1989; 46: 121-130.

9. Duarte MIS, Mariano ON, Takakura CFH, Uip DE, Corbett CEP. A fast method for processing biologic material for electron microscopic diagnosis in infectious disease. Ultrastruct Pathol, 1992; 16: 475-482.

10. Hill J O. Pathophysiology of experimental leishmaniasis: the role of parasite physiology in the development of metastatic disease. Am J Trop Med Hyg, 1988; 39: 256-260.

11. Vasconcellos, C. \& Sotto, M. N. - Experimental cutaneous leishmaniasis: transmission electron microscopy of the inoculation site. Int J Exp Path, 1997; 78: 81-89.

12. Magalhães A.V., Moraes M.A.P., Raick A.N., Llanos-Cuentas A., Costa J .M.L., Cuba C.C. \& Marsden P.D. - Histopatologia da leishmaniose tegumentar por Leishmania braziliensis braziliensis. 1. Padrões histopatológicos e estudo evolutivo das lesões. Rev I nst Med Trop São Paulo, 1986; 28 : 253-262.

13. Montenegro J . - Anátomo-pathologia da leishmaniose cutânea (úlcera de Bauru). An Paul Med Cirurgia , 1924; 15: 5-11. 